\title{
Fraus Legis in Constitutional Law: The Case of Expropriation "Without" or for "Nil" Compensation
}

M van Staden*

\section{P.E.R}

Pioneer in peer-reviewed, open access online law publications

Author

Martin van Staden

Affiliation

Member of the Rule of Law Board of Advisors, Free Market

Foundation

Email

m.vanstaden@sakeliga.co.za

Date Submission

12 March 2021

Date Revised

2 May 2021

Date Accepted

2 May 2021

Date published

28 June 2021

Editor Dr N Kilian

How to cite this article

Van Staden M "Fraus Legis in

Constitutional Law: The Case of

Expropriation "Without" or for

"Nil" Compensation" PER / PELJ

2021(24) - DOI

http://dx.doi.org/10.17159/1727-

3781/2021/v24i0a10406

Copyright

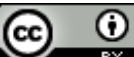

DOI

http://dx.doi.org/10.17159/1727-

3781/2021/v24i0a10406

\begin{abstract}
Fraus legis - defrauding or evading the application of law - is a phenomenon well-known to students of private law, but its application in public law, including constitutional law, remains largely unconsidered. To consider whether a transaction, or, it is submitted, an enactment, is an instance of fraus legis, an interpreter must have regard to the substance and not merely the form of an enactment. In 2018 Parliament resolved to amend section 25 of the Constitution of the Republic of South Africa, 1996 (the Constitution) to allow government to expropriate property without being required to pay compensation. While the public and legal debate has since before that time been concerned with "expropriation without compensation", the draft Constitution Eighteenth Amendment Bill, 2019 provides instead for expropriation where "the amount of compensation is nil". By the admission of Parliament's legal services unit, this is a distinction without a difference. But compensation and expropriation are legally and conceptually married, and as a result, it would be impermissible to expropriate without compensation - instead, nil compensation will be "paid". How does this current legal affair comport with the substance over form principle, and is fraus legis at play? This article considers the application of the fraus legis phenomenon to public law, utilising the contemporary case study of the Constitution Eighteenth Amendment Bill.
\end{abstract}

\section{Keywords}

Fraus legis; substance over form; expropriation without compensation; constitutional amendments. 


\section{Introduction}

Expropriation without compensation has probably been the most dominant topic in South Africa's public constitutional discourse since February 2018, when Parliament resolved that it would amend section 25 of the Constitution to enable government to expropriate property without necessarily being required to pay compensation. In December 2019 the draft Constitution Eighteenth Amendment Bill (the Amendment Bill) was published. As of April 2021, the text of the Amendment Bill remained unchanged but various alterations had been suggested. Notably, whereas the public discourse has consistently been concerned with expropriation "without" compensation, the Amendment Bill refers to expropriation for "nil" compensation. According to Parliament's legal services unit, this difference is intentional for doctrinal reasons, although the practical effect of "without" and "nil" compensation is the same.

Defrauding the law - acting in fraudem legis - is a recognised phenomenon in private law. Inter alia, fraus legis means doing indirectly what one cannot lawfully do directly. The result is that a court will pierce the veil of form and have regard to the substance of the matter. It has been rarely noted, however, that fraus legis applies to public law, including constitutional law, mutatis mutandis as it does to private law. This principle perhaps found its clearest elucidation in the majority judgment in Minister of the Interior $v$ Harris $^{1}$ and the dissenting judgment in Collins $v$ Minister of the Interior ${ }^{2}$ during the constitutional crisis of the 1950s.

In this article the question is posed whether the intentional use of "nil" in place of "without" in the Amendment Bill is an instance of Parliament's Ad Hoc Committee to Initiate and Introduce Legislation Amending Section 25 of the Constitution (the ad hoc committee) conducting itself in fraudem legis and thus whether the Amendment Bill is lawful. In other words, even if the Amendment Bill is adopted in line with the formal constitutional amendment requirements set out in section 74 of the Constitution, might it be invalid for another reason? In so considering, the nature of the fraus legis phenomenon is examined with reference to its customary use in private law and its application to public law. The article then contextualises

\footnotetext{
Martin van Staden. LLB LLM. Legal Fellow, Sakeliga. Member of the Rule of Law Board of Advisors, Free Market Foundation. Email: m.vanstaden@sakeliga.co.za. ORCID: https://orcid.org 0000-0002-4612-5250.

$1 \quad$ Minister of the Interior $v$ Harris 19524 All SA 376 (A) (hereafter the second Harris judgment).

2 Collins $v$ Minister of the Interior 19571 SA 552 (A) (hereafter Collins).
} 
expropriation without compensation and considers the text and intention behind the wording of the Amendment Bill. It is concluded that the ad hoc committee is attempting, unlawfully, to divorce compensation from expropriation by disguising the substance of its enterprise (no compensation) with a formal trick (nil Rands compensation). This amounts not only to fraus legis but offends both the founding values and basic structure of the Constitution. Parliament as such will therefore also make itself guilty of this phenomenon if it adopts the ad hoc committee's proposal and/or finally adopts the Amendment Bill, with its current employment of terminology, into law.

\section{Fraus legis}

\subsection{Overview}

The phenomenon of fraus legis facta is well-known in private law, such as private international law, tax law, and the law of contract. In this respect, fraus legis occurs "when parties to a transaction attempt to avoid the provisions of a statute or peremptory law by disguising the true nature of their transaction." In such cases: ${ }^{3}$

[t]hey are said to act 'in fraud of the law' (in fraudem legis); and once the situation is detected, the court will strip away the disguise and have regard to the true substance of the transaction rather than its outward form.

Clearly, thus, the phenomenon of fraus legis is similar, if not in some respects identical, to the substance-over-form principle adopted in South African constitutional discourse and law. ${ }^{4}$ According to Hutchison and Hutchison, fraus legis can occur in three ways: ${ }^{5}$

[f]irst, by disguising one's transactions in order to avoid the law; secondly, by structuring one's transactions so as to defeat the spirit (or purpose), although not the letter, of the law; or, thirdly, doing indirectly what one is not permitted by law to do directly.

They continue - again, in the context of private law - by arguing that to determine whether fraus legis has taken place, both the law and the transaction must be studied, and when this is done, the substance and not the form of the transaction must be relied upon. In substance-over-form

$3 \quad$ Hutchison and Hutchison 2014 SALJ 69.

$4 \quad$ Langa 2006 Stell LR 356-358; Hutchison and Hutchison 2014 SALJ 70; City of Tshwane Metropolitan Municipality v Afriforum 20166 SA 279 (CC) para 18.

5 Hutchison and Hutchison 2014 SALJ 69-70. 
analyses, courts must have regard to the true nature of a transaction or state of affairs, not merely the packaging, label, or appearance that it bears. ${ }^{6}$

Far from being doctrinally limited to private law, it is submitted that in South African law fraus legis: ${ }^{7}$

[s]imply expresses the principle according to which not shams but only true facts will be given effect to; in other words, the principle is represented by the proverb plus valet quod agitur quod simulate concipitur.

According to Van Dorsten, fraus legis has two requirements: intention and consequence. The intention must be "to escape the provisions of the law", and the consequence must be the undermining of the said law. ${ }^{8}$ These requirements, clearly, can apply to any legal phenomenon regardless of which division of law it falls within.

\subsection{Harris}

Employing fraus legis in a constitutional or public law context is not unknown in South African legal history, where it found expression in the early 1950s. ${ }^{9}$

In 1951 as part of its policy of apartheid the National Party government attempted $^{10}$ to remove the constitutionally entrenched common roll franchise of the coloured population of the then Cape Province by means of the Separate Representation of Voters Act 46 of $1951 .{ }^{11}$ In 1952 in Harris v Minister of the Interior ${ }^{12}$ the Appellate Division found the Act to be unconstitutional (or "invalid") as its process of enactment did not satisfy the requirements of sections 35 and 152 of the South Africa Act 9 Edw VII,

Hutchison and Hutchison 2014 SALJ 69-70.

Derksen 1990 THRHR 503.

8 Van Dorsten 1985 THRHR 384-385. Also see Hutchison and Hutchison 2014 SALJ 86-87.

9 This part deals with a limited aspect of South Africa's complex constitutional crisis of the 1950s. No comprehensive discussion of the crisis will be attempted here, merely a perhaps oversimplified summary. In this respect see Marshall Parliamentary Sovereignty 139-248; May South African Constitution 50-78; Van Staden 2019 EJW 273-277.

10 And ultimately succeeded. While what came after the second Harris judgment is very briefly considered below, this article does not fully contextualise the 1950s constitutional crisis.

11 The Separate Representation of Voters Act 46 of 1951 replaced the common voters' roll in the Cape Province with separate ones for "Europeans" and "non-Europeans". The only "non-Europeans" on the voters' roll at the time were those then classified as "coloured".

12 Harris $v$ Minister of the Interior 19522 SA 428 (A) 472D (hereafter the first Harris judgment). 
which at the time was formally South Africa's constituent law. ${ }^{13}$ Because of its belief in the doctrine of parliamentary sovereignty, the National Party government sought to invalidate the Court's judgment. ${ }^{14}$

One of its first attempts to do so came in the same year, in the form of the High Court of Parliament Act 46 of 1951. That Act established a so-called "High Court of Parliament"15 and declared "[e]very senator and every member of the House of Assembly [to be] a member of the Court."16 The intention was for this "court" - Parliament itself - to review (and set aside) the first Harris judgment, ${ }^{17}$ and presumably any other Appellate Division judgment that did not sit well with the parliamentary majority. The unanimous Appellate Division, too, per Centlivres CJ, found the High Court of Parliament Act to be unconstitutional, because it was impermissible for Parliament to "pass any Act, the effect of which would be to render nugatory the rights entrenched in the Constitution", ${ }^{18}$ and that "[t]he practical effect of a decision of the High Court of Parliament ... would be the same as legislation repealing the safeguards contained in sec. 152 of the Constitution."19 It is evident that the Appellate Division was dealing with the substance of the High Court of Parliament, not its form. ${ }^{20}$ The Court concluded that while in form the High Court of Parliament was a court of law, in substance it was "simply Parliament functioning under another name". ${ }^{21}$

In a concurring judgment, Van den Heever JA remarked as follows: ${ }^{22}$

[counsel for the government] perhaps rashly, conceded that the principle of fraus legis is applicable to acts of a legislature. If the Roman-Dutch law relating to fraus legis, properly understood, were to be applied to the present dispute, appellants would be out of court. This, however, is hardly the occasion to enter upon that enquiry. ... If a Legislature devises a measure to repress some

S 35 of the South Africa Act 9 Edw VII provided that Parliament may not enact legislation that disqualifies anyone who qualified to be on the roll at the time of the Act's adoption (1910) on the grounds of race or colour, from the Cape Province's voters roll. S 152 in turn provided that Parliament may not repeal or alter (inter alia) s 35 unless it does so by a two-thirds majority in a joint sitting of the lower and upper houses of Parliament.

14 Marshall Parliamentary Sovereignty 185.

15 S 2 of the High Court of Parliament Act 46 of 1951.

16 S 3(1) of the High Court of Parliament Act 46 of 1951.

17 The so-called High Court of Parliament met on 25 August 1952 and set the first Harris judgment aside. See May South African Constitution 60.

18 Second Harris judgment 381. My emphasis.

19 Second Harris judgment 383. "The Constitution" here refers to the South Africa Act.

20 Centlivres CJ remarked that "[w]ere this Court only to look at the form of legislation, constitutional guarantees might be of very little value". Second Harris judgment 384.

21 Second Harris judgment 385.

22 Second Harris judgment 394-395. 
mischief it should direct its words to the mischief itself; if it chooses to set about its task by indirect methods, that is by barring avenues to the realisation of the mischief and does not succeed in doing so exhaustively, that is the misfortune of the Executive, not of the subject. ... [l]f the statute we have to interpret expressly applied curbs on legislative powers in the interests of the subject and has entrusted to the courts, if their aid is invoked, the duty of protecting the rights of the subject against the enactment of measures which purport in excess of such power to deprive citizens of guaranteed constitutional rights. In such a case a Court would not be doing its duty if by mechanical adherence to words it allowed the patent intention of the constituent Legislature to be defeated and the rights to be proscribed.

Commenting on the above portion of Van den Heever JA's judgment and a similar warning from the Privy Council in a different case concerning Ceylon, Beinart writes that: ${ }^{23}$

[a] legislature cannot do indirectly what it cannot do directly, and that it was the Court's duty to enquire into the true character, the 'pith and substance' of legislation, which is claimed to defeat a constitutional guarantee. Although the Court will not easily assume such an intention on the part of the legislature, there might nevertheless be circumstances in which Legislation though framed so as not to offend directly against the constitution, indirectly achieved the same result, in which case it would be ultra vires.

It is submitted, therefore, that fraus legis can - and does - have public law, constitutional application.

The utilisation of the second Harris judgment in this article should not be misconstrued. It is evidently a seven-decade old case and found itself in a constitutional dispensation quite unlike that South Africa functions under today. While the second Harris judgment undoubtedly forms part of South African law, then, it is utilised here mostly for its persuasive value: The case is noteworthy because the apex South African court at the time dealt with a substance-over-form or fraus legis matter in the context of constitutional law, and particularly in the context of Parliament's legislative power. That makes it a relevant case to consider in the context of the proposed amendment of the Constitution today.

Moreover, if it was thought that fraus legis applied to public law, particularly to the legislative powers of Parliament, during the pre-constitutional era, then it is submitted that the dawning of constitutional democracy in the 1990s did not weaken this position. If Parliament was, in theory at least, required to act in good faith, transparently, and not engage in underhand machinations to achieve legally unachievable outcomes ${ }^{24}$ during the time of

\footnotetext{
23 Beinart 1954 BSALR 181.

24 Why expropriation without compensation is legally unachievable is explored below.
} 
parliamentary sovereignty, then it is argued that it is certainly required to conduct itself in good faith during the time of constitutional supremacy. ${ }^{25}$

\subsection{Collins}

The Collins case is similarly relevant when considering the phenomenon of fraus legis as applied to public law. In this case, the Senate Act 53 of 1955 provided that the number of senators be expanded from 48 to 89 . The result was that the National Party government manufactured for itself the requisite two-thirds majority in both houses of Parliament sitting together, and thereupon validated the Separate Representation of Voters Act in an ostensibly legal manner, as required by the South Africa Act. ${ }^{26}$ The Senate Act was subsequently challenged, inter alia on the basis that it was nothing more than an apparently lawful vehicle to achieve an unlawful result. In this case, however, unlike both the prior Harris judgments, the Appellate Division found for the government.

The Chief Justice, for the majority, held that both the Senate Act, taken by itself, and the subsequent validation of the Separate Representation of Voters Act, taken by itself, were lawful, and that Parliament's intention was irrelevant at law. ${ }^{27}$

One must, however, not lose sight of the fact that the Appellate Division's bench had been expanded from five judges to eleven by the Appellate Division Quorum Act 27 of 1955. Centlivres CJ, Schreiner JA, and Hoexter $\mathrm{JA}$, who had previously found against government inter alia on the grounds of substance over form were now outnumbered by additional judges who, with respect, were probably (perhaps inter alia) appointed based on the likelihood of them in casu finding for government. We do not have access to the discussions that had taken place between the existing and additional judges in chambers prior to the delivery of the Court's decision, but it is submitted that (from a legal realist perspective ${ }^{28}$ ) there was peer pressure inter alia on the Chief Justice to pen the judgment that he did. Only

25 See in this regard ss 1, 41(1), 195(1), and 237 of the Constitution.

26 The vehicle for this was the South Africa Act Amendment Act 9 of 1956.

27 Collins 564-565.

28 The main thrust of the legal realist argument, which it is submitted is correct, is that judges do not always reach their conclusions based on what the law requires, but that other factors, primarily judges' own ideological preconceptions, also influence the content of their judgments. In this case it is submitted that peer pressure and perhaps a desire to put an end to the tiresome and stressful so-called constitutional crisis could have had a significant effect on those two judges who had previously ruled against the government in the Harris judgments, to rule in its favour in Collins. 
Schreiner JA, a noted principled liberal, ${ }^{29}$ dissented, and his dissenting judgment was in line with the approach the Court adopted in the first and second Harris judgments. ${ }^{30}$

Interestingly, however, the Chief Justice and majority seem to have not abandoned entirely the principle that fraus legis applies in public law. In fact, the Chief Justice made it explicit that it did so apply, when he argued: ${ }^{31}$

Thus in spite of the fact that the widest possible powers are conferred on Parliament sitting bicamerally, those powers are subject to the proviso to sec. 152. For instance, Parliament sitting bicamerally cannot in reconstituting the Senate provide that membership shall be confined to persons who speak and write English or to persons who can speak or write Afrikaans. Such a proviso would, pro tanto, be an alteration to section 137.

In other words, Parliament could not lawfully attempt to achieve something indirectly that it cannot lawfully do directly. However, later the Chief Justice said that "Parliament sitting bicamerally had plenary powers to reconstitute the Senate in any manner it pleased and that the purpose or motive which it had in mind is irrelevant in law."32

As Van Dorsten put it, however, intention is an element of fraus legis, and to accept the Chief Justice's reasoning would mean that fraus legis is impossible with regard to enactments by a legislative body. These remarks by the Chief Justice, it is submitted, must either be regarded as off-the-cuff or incorrect. If Parliament's intention is entirely irrelevant in law, then Parliament can engage in all manner of (formally lawful) trickery to achieve substantively unlawful ends. Substance over form as a legal principle would be extinguished.

It is submitted in this regard that Schreiner JA was correct in his dissenting judgment that "all the circumstances surrounding and leading up to the passing of that Act will have to be taken into account to see whether the [law has been complied with]". ${ }^{33}$ He continued, arguing that the principle (effectively of fraus legis in public law) "should apply where the obstacle is a constitutional protection against legislation and the attempted means of avoiding it is legislative." ${ }^{34}$ In his dissent Schreiner JA approvingly quotes from the judgment in Pillai $v$ Mudanayake, wherein the Privy Council said that "It must be shown affirmatively by the party challenging a statute which

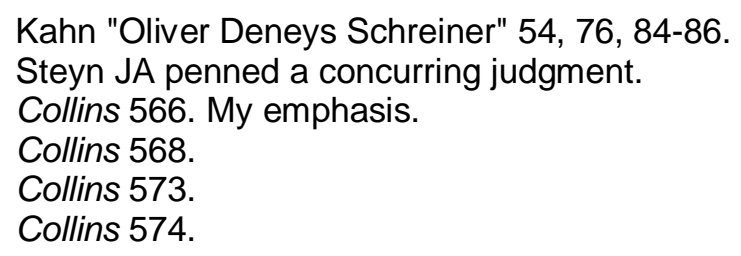


is, on its face, intra vires, that it was enacted as part of a plan to effect indirectly something which the Legislature had no power to achieve directly." 35 As such, Schreiner JA concludes that "the plan and the purpose" of a legislature "may be crucial to validity" of its enactment, if that plan is "to do indirectly what the Legislature has no power to do directly." 36 Schreiner JA therefore concluded that: ${ }^{37}$

[t]he Senate Act was part of a legislative plan to create a Senate that would in that way provide the two-thirds majority required to remove the appellant from the common roll, and that it was enacted only for that purpose. For these reasons I would allow the appeal and grant an order declaring the South Africa Amendment Act 1956 to be of no legal force and effect.

Schreiner JA's substance over form approach, it is submitted, fits more appropriately with South Africa's present constitutional order, as opposed to the majority's excessively formalist reasoning that refused to take the broader context into account.

\section{Expropriation "without" or for "nil" compensation}

\subsection{Context}

The contemporary case study for the application of the fraus legis phenomenon in South African constitutional law is the proposed Amendment Bill, which contains a conceptualisation of expropriation "without" (or for "nil") compensation. The proposed amendment to the Constitution must be seen against the backdrop of the continued controversy around land reform in post-apartheid South Africa. A brief contextualisation which will omit and simplify various important aspects and dimensions of the land debate will suffice.

It is trite that the white minority governments of the past engaged in what would today be considered illegitimate dispossession of landed property as part of its programme of social engineering. It sought to divide South Africa into relatively contiguous regions for blacks, whites, coloureds, and persons of Indian descent. This meant that those who found themselves outside of "their" assigned regions often had to be moved there, against their will if necessary. This initiative had two interrelated dimensions: Firstly, grand apartheid, with its foundation inter alia in the Natives Land Act 27 of 1913 and the Native Trust and Land Act 18 of 1936, was specifically (and perhaps ostensibly) aimed at separating black South Africans (on the one hand) from

Pillai v Mudanayake 19552 All ER 833837.

Collins 577.

Collins 582. 
white, coloured, and South Africans of Indian descent (on the other hand) in a process of denationalisation. Eventually the regions into which blacks were moved - chronologically called reserves, homelands, and national states $^{38}$ - were intended to become sovereignly independent from the Republic of South Africa, ensuring that the white population made up the majority of the remaining population in South Africa. Secondly, petty apartheid was meant to apply in this so-called "white South Africa", inter alia to ensure that whites, coloureds, and persons of Indian descent each kept to their own residential and commercial areas. Black persons who came into South Africa from the homelands as "temporary sojourners" were also to have their own residential and commercial areas. Petty apartheid was based mostly, but inter alia, on the Natives (Urban Areas) Consolidation Act 25 of 1945 and the various Group Areas Acts 14 of 1950, 77 of 1957, and 36 of 1966, as amended.

Since the period of transition out of apartheid and into constitutional democracy of the 1990s, the necessity of a land reform programme of some description has been controversial and widely debated. Proponents of land reform argue that the property - usually spoken of in the context of "land" dispossessed for the purposes of implementing apartheid must be returned to those from whom it was taken. ${ }^{39}$ Section 25 of the Constitution in large part provides for land reform.

While the approach adopted in this article contests the legitimacy of the Amendment Bill, and by implication government's approach to land reform, the necessity of the restitution of property dispossessed during the colonial and apartheid eras is not disputed. It is indeed an essential principle of the theory of private property rights that property taken without justifiable cause must be returned to those from whom it was taken, or alternatively the latter must be compensated for the loss. ${ }^{40} \mathrm{It}$ must, however, be borne foremost in mind that the current holder of the property is not necessarily blameworthy for the initial dispossession, and if they are, such blameworthiness must first

38 Egerö South Africa's Bantustans 6.

39 Some, usually from quarters closer to government, also argue for redistribution and nationalisation, not merely restitution. See for instance Cronin 2018 https://www.dailymaverick.co.za/article/2018-07-23-its-land-reform-not-narrowexpropriation-without-compensation/. Returning dispossessed property to its rightful owner(s) or their descendants in title is materially different, it is submitted as both a matter of fairness and justice, from seizing random properties and distributing them to others in pursuit of some demographic quota formula, or vesting ownership of such properties in the State. This argument is not the focus of this article however The existence of the common law remedies rei vindicatio and actio ad exhibendum are a clear indication of this. Also see s 2 of the Restitution of Land Rights Act 22 of 1994. 
be proven. In the absence of such blameworthiness, however, as will be discussed under the next heading, compensation for the expropriation of the property they hold is of central importance, particularly in a constitutional democracy based inter alia on the value of human dignity. ${ }^{41}$

\subsection{Expropriation and compensation}

\subsubsection{Constitutional text}

The ad hoc committee has been advised of and has accepted the notion that compensation for expropriation of property is not legally necessary and moreover not necessarily required by the Constitution even in its preamended form. This has taken the form, most prominently, of the notion that the Amendment Bill, if enacted, would simply "make explicit that which is implicit" in the Constitution already - that property may be expropriated without compensation. ${ }^{42}$

Such an argument must be rejected, not only on the strength of the text of the Constitution but also on its values. Elsewhere it has been argued that the constitutional reference to an "amount" of compensation eliminates the possibility that it was possible for government to expropriate property without compensation prior to amending the Constitution. ${ }^{43}$ It is also worth noting that how one can be paid (also required by section 25(3) of the Constitution) an "amount" of nil Rands is perplexing. The constitutional use of the phrase "time and manner of payment" clearly contemplates an action or commission. It is furthermore submitted that to conceive of this action as merely informing expropriated owners that they have been "paid" the "amount" of nil Rands would make a mockery of the principle of substance over form, and would furthermore make a mockery of the constitutional text if its words can be misconstrued and misapplied in such a fashion. ${ }^{44}$

41 It can hardly be claimed that expropriated owners are treated as "ends in themselves" rather than mere "means to an end" if their livelihoods and interests are so radically disregarded so as to give them nothing for their most valuable assets. See generally Steinmann 2016 PELJ.

42 Preamble to the Draft Constitution Eighteenth Amendment Bill, 2019. Also see Hall $2018 \mathrm{https}$ ://www.iol.co.za/capetimes/opinion/landexpropriation-for-what-landreform-for-whom-your-land-questions-answered-16370960.

43 Van Staden 2020 PSLR 172.

44 It will be noted that this article does not enter into the controversy around marketvalue compensation and its relationship to the standard of "just and equitable" compensation found in s 25(3) of the Constitution. 


\subsection{2 "Expropriation without compensation" is a contradiction in terms}

It is submitted in addition that expropriation and compensation are inherently and conceptually tied to one another. Grotius coined the notion of eminent domain in On the Law of War and Peace. He is for all intents and purposes the progenitor of the contemporary notion of expropriation. ${ }^{45}$ Grotius acknowledged the power of the State to expropriate property in cases of "extreme Necessity" and even "publick Benefit", but "[added], that the State is obliged to repair the Damages, sustained by any Subject on that Account, out of the publick Stock" and that "the State [shall not] be released from this Obligation" when it has the capacity to fulfil it, ${ }^{46}$ even during wartime. ${ }^{47}$ Reynolds goes as far as to argue that even before Grotius, it was simply assumed even in parts of Africa that it was wrong for land to be seized without compensation, and thus there was no need for such a fact to be reduced to writing. She goes further, noting that the contentious detail was (and remains) to determine the amount of compensation, and furthermore, how to guarantee that vulnerable expropriated owners would actually be paid. ${ }^{48}$ The assumption, Reynolds argues, that compensationupon-expropriation was somehow novel by the time of the American Revolution and the codification of the right to compensation in the American Bill of Rights and elsewhere is incorrect. ${ }^{49}$ The fact that compensation had as a general rule always been paid in past practice, and that it went undebated during the American Constitutional Convention, showed that requiring the payment of compensation was uncontroversial. ${ }^{50}$ It is evident, then, that the lack of an explicit historical legislative or constitutional guarantee of compensation is no reason to regard expropriation and compensation as separate or only recently married. It was, to greater and lesser extents, always simply assumed, rightly, that expropriations must involve compensation.

Epstein explains the reason why compensation is always payable upon expropriation: 51

\footnotetext{
$45 \quad$ Reynolds Before Eminent Domain 85.

$46 \quad$ Grotius On the Law of War and Peace Book III 1556.

47 Warchuk 2015 UBC Law Rev 686.

48 Reynolds Before Eminent Domain 10-11, 13.

49 The Fifth Amendment to the Constitution of the United States of America, 1789, provides, "No person shall ... be deprived of life, liberty, or property, without due process of law; nor shall private property be taken for public use, without just compensation."

$50 \quad$ Reynolds Before Eminent Domain 82.

$51 \quad$ Epstein 2014 Touro L Rev 274.
} 


\begin{abstract}
The just compensation requirement ensures that the individual, who has been forced by law to contribute property to some common improvement, is not wiped out in the process. The just compensation requirement assures that the state's option to compensation can never be exercised at zero price, but only at fair market value. Done correctly, no one gets hurt, and any social improvement remains.
\end{abstract}

This stands to reason. Expropriated owners are not criminals, nor have they been found liable for a delict. Expropriation, in other words, is not a tool for legal punishment. Where legal subjects are guilty of offences or delicts, the law offers other ways of punishment, including the law of criminal asset forfeiture ${ }^{52}$ or compensation for damage caused, by way of the actio legis Aquiliae. ${ }^{53}$ Instead, expropriation is exclusively concerned with "social improvement" - in South Africa, the "public interest" or "public purposes" rather than with harming owners whose property has been targeted for expropriation. Bona fide holders of property must be compensated to ensure they are not placed in a significantly worse position than before the expropriation. ${ }^{54}$ There is therefore arguably never any good reason to contemplate not paying compensation. Compensation and expropriation, in other words, are inextricably tied together. It is submitted, therefore, that it is a contradiction in terms to speak of either "expropriation without compensation" or expropriation where "the amount of compensation is nil". Instead, what Parliament, with its February 2018 resolution and the ad hoc committee with the Amendment Bill are contemplating is some other form of confiscation of property. ${ }^{55}$

This line of argument will no doubt be challenged. But it is submitted that even if it is the case that compensation is not strictly necessary, it remains reasonably necessary within the context of a constitutional democracy founded on the values of freedom, human dignity, and equality, again bearing in mind that there is no reason to conceive of expropriated owners as wrongdoers in the absence of proof of mala fides. Warchuk writes that "[g]eneral principles of justice and fairness support" the view that owners ought to be compensated when their property is expropriated for some public purpose. ${ }^{56}$

Additionally, if the argument that expropriation and compensation are inherently conceptually tied is unconvincing, there is still the further matter

\footnotetext{
52 See for instance Part 3 of the Prevention of Organised Crime Act 121 of 1998.

53 Oosthuizen Law of Property 60.

54 Van Staden 2020 PSLR 189.

55 The existing terminology is utilised herein, however, due to its ubiquity. 
that compensation for expropriation is required by international law ${ }^{57}$ and, furthermore, it is customary in all open and democratic societies of the world. ${ }^{58}$ Finally, it has been argued elsewhere that expropriation without compensation could be contrary to the basic structure of the Constitution, and therefore any so-called "amendment" to bring it about might not amount to Parliament exercising its amendment power at all but rather destroying the Constitution and replacing it with another constitution. ${ }^{59}$ The basic structure doctrine identifies certain core characteristics of a constitution's identity and posits that if any such characteristic is removed that constitution loses its identity and is replaced with another. ${ }^{60}$

\subsubsection{International law and best practice}

Before turning to international law per se, it is worth noting the implicit nature of the right to compensation. Reynolds' work, as canvassed above, shows that compensation upon expropriation is something that for most of legal history has simply been assumed and was not necessarily always statutorily defined. The lack of an explicit basis of the right to compensation does not mean it was absent. This must be borne foremost in mind when considering the following aspects of international law, for in these instruments no explicit, so-called "right to compensation" exists. It is submitted in addition that the right to compensation upon expropriation is something that must be read into any apparent recognition or protection of the property rights of legal subjects, for indeed in the absence of the guarantee of compensation it can scarcely be argued that the property right in question has any content. If the State may simply confiscate property without providing something of equivalent value in return, it cannot be said that any property rights exist in the first place, for a "right", particularly a fundamental right, necessarily implies a (substantive) protection of the relevant legally recognised interest.

With this context in mind, the protection of property rights in international law is now considered. One of the purposes of the United Nations, as taken up in Article 1(3) of the Charter of the United Nations, is through international cooperation to promote and encourage "respect for human rights and for fundamental freedoms for all without distinction as to race, sex, language,

\footnotetext{
57 See generally Moore 2018 https://ruleoflaw.org.za/2018/05/21/whetherexpropriation-without-compensation-would-violate-sas-treaty-or-international-lawobligations/.

$58 \quad$ Van Staden 2020 PSLR 188-189.

59 Van Staden 2020 PSLR 179-180, 193.

$60 \quad$ Van Staden 2020 PSLR 176-177.
} 
or religion". Article 17(1) of the Universal Declaration of Human Rights, ${ }^{61}$ in turn, provides that "Everyone has the right to own property alone as well as in association with others", and sub-article (2) provides that, "No one shall be arbitrarily deprived of his property". South Africa is a founding member of the United Nations. ${ }^{62}$

In 1928, some years before the United Nations was established, Dunn wrote of the: 63

\begin{abstract}
[a]Imost unanimous agreement among the authorities [on international law] that a nation which, in the exercise of its territorial sovereignty, does not observe the standard of justice of civilized states in its treatment of foreigners incurs responsibility to the governments of the countries to which those foreigners belong for any injury which they may sustain.
\end{abstract}

In other words, so-called standards of justice were regarded as enforceable between states inter se. Dunn was focussed mainly on the position of foreigners, as opposed to citizens of the respective state whose property rights were threatened. However, such a distinction between citizen and foreigner is today of less relevance, especially with the substantial elevation of the idea that every individual has an inherent human dignity that must be recognised, respected, and protected. This elevation occurred chiefly after the Second World War internationally but in South Africa particularly this happened at the end of apartheid, with human dignity and equality (in casu, between citizen and foreigner) not only being taken up as constitutional rights but also as underlying constitutional values. ${ }^{64}$ The Second World War, and particularly the Holocaust in Germany, represents one of the main watershed moments when "the standard of justice" that exists in international law came to be regarded as applicable between a state and its

An admittedly non-binding but nonetheless instructive instrument. See Sprankling 2014 Colum J Transnat'l L 4. For instance, the preamble to the Resolution on Respect for the Right of Everyone to Own Property Alone as well as in Association with Others and its Contribution to the Economic and Social Development of Member States UN Doc A/RES/41/132 (1986), Sprankling argues, "acknowledges that the nonbinding right to property in the Universal Declaration was incorporated into the [Convention on the Elimination of All Forms of Discrimination Against Women], a binding treaty". The preamble's language said that the right to own property as found in the Universal Declaration of Human Rights (1948) was "reaffirmed" by Art 16 of the Convention on the Elimination of All Forms of Discrimination Against Women (1979), which provides that women be allowed to own, acquire, etc., property on an equal basis. See Sprankling 2014 Colum J Transnat'l L 12-14.

62 UN Library 2021 https://research.un.org/en/unmembers/founders.

63 Dunn 1928 Colum L Rev 175.

64 See in this respect ss 1(a) and 36(1) of the Constitution. Also see Sprankling 2014 Colum J Transnat'l $L 21$ on how international law has developed to regulate the relationship between states and non-state actors. 
own people in its own jurisdiction. ${ }^{65}$ It is submitted that an argument that a state need simply recognise, respect, and protect the dignity, liberty, or property of foreigners within its territory but not that of its own citizens would not be sustainable today, especially in South Africa.

Sprankling is therefore correct to argue that "the view that property rights are exclusively governed by national law is increasingly obsolete" and that: 66

[t]he evolution of international law has reached the point where a global right to property should be recognized, not merely as a moral principle but rather as an entitlement which all nations must honor.

Sprankling submits that international treaties against discrimination "arguably recognize the right to property may provide a basis for justifying the right under conventional law"; that the right to property is a general legal principle because it is ubiquitously recognised as a legal right around the world; and that it is also a right of international customary law because of the same global ubiquity. ${ }^{67}$ Article 14 of the African Charter on Human and Peoples' Rights provides that: 68

The right to property shall be guaranteed. It may only be encroached upon in the interest of public need or in the general interest of the community and in accordance with the provisions of appropriate laws.

The right to property is also recognised inter alia in the European Convention for the Protection of Human Rights and Fundamental Freedoms, the American Convention on Human Rights, the Arab Charter on Human Rights, and the ASEAN Human Rights Declaration. ${ }^{69}$

Sprankling further submits that the right to property is inherently implicit in various anti-discrimination treaties. Article 16(h) of the Convention on the Elimination of All Forms of Discrimination Against Women, Article 5(v) of the International Convention on the Elimination of All Forms of Racial Discrimination, Article 15 of the International Convention on the Protection of the Rights of All Migrant Workers and Members of Their Families, and Article 12(5) of the Convention on the Rights of Persons with Disabilities

\footnotetext{
65 Buergenthal "International Law and the Holocaust" 6.

66 Sprankling 2014 Colum J Transnat'' L 1-2.

67 Sprankling 2014 Colum J Transnat'l L 2.

68 The universally recognised authority of governments to "encroach" or limit the exercise of property rights in terms of law is not disputed in this article. It is submitted, however, that there is a material difference of several orders of magnitude between limiting the right to property in line with accepted standards and best practice and confiscating property without providing compensation. 
recognise the existence of a pre-existing right to property and insist that this right be enjoyed equally by vulnerable groups. "Thus, if the implied recognition approach is justifiable," argues Sprankling, "it is fair to say that today the right to property is almost universally recognized in conventional law."70

The main thrust of Sprankling's argument, however, is based on the notion that the right to property is a general legal principle, and that it is also a part of customary international law, which is unequivocally binding on states.

In the first respect, Sprankling notes that almost all the member states of the United Nations guarantee the right to property in their national constitutions. As a result: ${ }^{71}$

\section{The near-unanimous recognition of the right to property qualifies it as a general principle of law at the international level which will bind all nations ... This approach would extend the global right to nations which are not parties to regional human right treaties, avoiding the need to rely on the [above] implied recognition theory.}

In the second respect, Sprankling notes the requirements of a principle becoming part of customary international law: adherence to a practice in the belief that it is required by international law. ${ }^{72}$ The requirement of adherence is satisfied by the fact that almost all states recognise the right to property and, it is submitted, all the open and democratic societies of the world recognise and guarantee the right to compensation upon expropriation. In addition to examples mentioned elsewhere, ${ }^{73}$ even Article 13 of the Constitution of the (formally) communist People's Republic of China recognises and entrenches the right to property, as well as the right to the payment of compensation when that property is expropriated. Sprankling notes that the content of a right to property recognised in international law will be contentious, ${ }^{74}$ but it is submitted that international best practice is instructive in this regard, and in the present context such practice does necessitate the payment of compensation.

The second requirement - opinio juris or the belief that something is necessitated by international law - is more complex, according to Sprankling. One manner of identifying opinio juris is to consider state conduct in its adoption of international treaties. Thus, for instance, if a state

Sprankling 2014 Colum J Transnat'l L 12-14.

Sprankling 2014 Colum J Transnat'I L 16.

Sprankling 2014 Colum J Transnat'l L 22.

Van Staden 2020 PSLR 188-189.

Sprankling 2014 Colum J Transnat'l L 31. 
adopted an international instrument that recognises the right to property, it had implicitly acknowledged that respecting the right to property is indeed required by international law. To Sprankling, "the consistent endorsement of the Universal Declaration by virtually all nations is evidence of opinio juris as to the right to property and its other provisions." ${ }^{75}$ Furthermore, opinio juris represents little difficulty in the present South African situation. As will be seen below, Parliament's legal services unit has advised the ad hoc committee that compensation upon expropriation is a necessity, and although international law is not mentioned - instead international best practice is referred to - it is clear that the acceptance by the ad hoc committee of this advice means that the parliamentarians involved agree with legal expert opinion that expropriation without compensation is a lawfully unachievable phenomenon.

Commenting on section 25 of the Constitution of South Africa, Sprankling notes that it does, in fact, require the payment of compensation, and that very few constitutions around the world "allow the expropriation [of] property owned by their citizens, at least in some situations, with no compensation", pointing to only two examples, viz. Venezuela and Zimbabwe. ${ }^{76}$

\subsubsection{Property rights in the basic structure of the Constitution}

The contours of the basic structure doctrine in the South African legal context have been sketched elsewhere in detail. ${ }^{77}$ Here it is only necessary to advance the argument that property rights, particularly the right to compensation upon expropriation, as contained in sections 25(1)-(3) are in fact part of the basic structure of the Constitution. Elsewhere it was briefly submitted that property rights might be part of this basic structure because various other rights and provisions in the Constitution assume the recognition and protection of property rights, and that the values underlying the Constitution, particularly those listed in section 1 , provide a radiating protection for property rights as ensconced in section $25 .{ }^{78}$

In the present article no new ground will be trodden. Instead, it is submitted, in the light of the fact that (it is argued) it has been shown that expropriation and compensation are conceptually entwined and cannot rightly be separated, that property rights (and by necessary implication, compensation for expropriation) form part of international law (as a matter of treaty law, as

\footnotetext{
75 Sprankling 2014 Colum J Transnat'I L 23-24.

76 Sprankling 2014 Colum J Transnat'I L 26.

77 See generally Van Staden 2020 PSLR.

78 Van Staden 2020 PSLR 187.
} 
a ubiquitously accepted principle of law across national boundaries, and as a clear rule of international customary law), that compensation is best practice around the world, and that compensation upon expropriation is necessitated by (at least) the constitutional value of respecting human dignity, that expropriation without compensation is a phenomenon incompatible with the basic structure of the Constitution.

In the light of all the above, it is submitted that expropriation without compensation is a phenomenon the law cannot legitimately condone. The ad hoc committee, as will be seen below, appears to acknowledge this fact. Rather than allowing for expropriation without compensation, then, the ad hoc committee seeks to still require compensation in all cases, provided that in some cases compensation can be "nil". The nature of such a legislative disguise is considered below.

\subsection{Constitution Eighteenth Amendment Bill}

It is worth briefly considering what the Amendment Bill, as of April 2021, provides for. This has been done elsewhere in more detail. ${ }^{79}$

Clause 1(a) of the Amendment Bill amends section 25(2)(b) of the Constitution, which requires compensation to be paid for expropriation. After amendment, section 25(2)(b) will provide that a court may "determine that the amount of compensation is nil". Clause 1(c) of the Amendment Bill furthermore provides that Parliament must in legislation determine under which circumstances a court may so determine. ${ }^{80}$

It is likely that changes will be made to the Amendment Bill before it is considered by Parliament. ${ }^{81}$

\section{4 "Without" versus "nil"}

The public discourse, even before Parliament resolved in favour of amending the Constitution in February 2018, has been concerned exclusively with "expropriation without compensation", often abbreviated to "EWC". 82 The Amendment Bill, on the other hand, as seen above, refers to

\footnotetext{
79 Van Staden 2020 PSLR 173-174.

80 At the time of writing, it had been suggested that the courts' role in this process be largely replaced with an executive authority.

81 Azzakani 2021 https://www.parliament.gov.za/press-releases/media-statement-adhoc-committee-s-25-adopts-report-public-participation.

82 See for instance Hlomendlini and Makgolane 2017 https://www.blsa.org.za/assets/ Uploads/2017-July-Possible-impact-of-land-expropriation-on-the-agric-sector-27-
} 
"nil" compensation. Prima facie this is a purely semantic difference, with the effect being exactly the same. This is correct. What the change in terminology does bring to light, however, is the issue of methodology, process, and intention.

A document from the Constitutional and Legal Services Office (CLSO) of Parliament dated 12 February 2021 lists certain proposed changes to the wording of the Amendment Bill. The proposals at issue invariably propose inserting the words "without compensation" into the Amendment Bill as it relates to compensation for expropriated property. This is the CLSO's response: ${ }^{83}$

\begin{abstract}
Property experts advised the committee that the concept of 'compensation' is required as a part of the process of expropriation. Compensation as a concept is closely linked to the concept of expropriation. This is globally accepted. The Bill can thus not exclude the concept (by using the phrase 'without compensation'), but the Bill can make the amount of compensation nil Rand, which in practice has the same effect (the land will be expropriated without the State having to pay money for it), and is a legally sound formulation.
\end{abstract}

In a later public presentation to the ad hoc committee, ${ }^{84}$ the CLSO further 1) acknowledged the application of the basic structure doctrine in South Africa, ${ }^{85}$ and 2) that property rights and the requirement of compensation are "imperative" and part of the basic structure of the Constitution. ${ }^{86}$

The CLSO, therefore, effectively recognises the reality that expropriation and compensation are conjoined concepts as elucidated by Grotius, Epstein, and others. Given that Parliament has decided that it wishes for government to have the power in practice to pay nothing when it expropriates property, however, the language the ad hoc committee has decided upon (and why the proposed revisions to the Amendment Bill cannot be accepted) is "nil compensation", implying that an "amount" of nil Rands will sometimes be "paid" when property is expropriated. This is regarded as a workaround that saves the Amendment Bill (and Parliament's

July2.pdf; Luke 2015 https://www.futuredirections.org.au/publication/challengesconfronting-south-africa-land-reform/; Wa Mutua 1997 Harv Hum Rts J 80. Constitutional and Legal Services Office 2021 https://pmg.org.za/files/210331Annexure_A.docx. Parliament 2021 https://www.youtube.com/watch?v=Pb_bd3bdPZA. The CLSO presentation starts at $01 \mathrm{~h} 01 \mathrm{~m} 30$. Parliament 2021 https://www.youtube.com/watch?v=Pb_bd3bdPZA. The CLSO presentation at around $01 \mathrm{~h} 09 \mathrm{~m} 15$.

Parliament 2021 https://www.youtube.com/watch?v=Pb_bd3bdPZA. The CLSO presentation at around $01 \mathrm{~h} 11 \mathrm{~m} 00$. It must be noted, however, as explained below, that the CLSO believes the manner to get around the application of doctrine of the basic structure is to employ the language of "nil compensation", which, in its view, solves the problem of unconstitutionality. 
desire for an additional government power) from the unconstitutionality that would result if it provided for expropriation "without compensation". 87

\title{
4 The Amendment Bill and fraus legis
}

This reality must once more focus attention on the phenomenon of fraus legis. It is useful at this juncture, therefore, to revisit Hutchison and Hutchison's three methods of defrauding the law and to apply them to constitutional amendments. While each of these methods is considered in turn, there is a significant degree of overlap between all three.

First, however, the remarks of Allen, from another common law jurisdiction and in the context of expropriation, are noteworthy: ${ }^{88}$

\begin{abstract}
In the common law world, judges are fond of saying that constitutional interpretation should focus on substance rather than form. But what, precisely, does this mean? No judge would allow the legislature or executive to use artificial or technical distinctions to circumvent constitutional restrictions on their power. Fundamental rights, in particular, are given careful protection. This applies as much to the right to property as any other right.
\end{abstract}

This is notable as it ties fraus legis once more, to the substance-over-form principle that is arguably an imperative of South Africa's post-apartheid constitutional dispensation.

\subsection{Disguising conduct to avoid the law}

Applying the first ("disguising one's transactions in order to avoid the law") of Hutchison and Hutchison's three methods to the Amendment Bill, one might argue that fraus legis can occur when a constitutional amendment seeks to achieve an unlawful purpose by disguising itself in the terminology of legality. This would not change the fact that the ad hoc committee is acting unlawfully. As Centlivres CJ remarked in the second Harris judgment, an "enactment must be judged by its substance and not by the nomenclature it uses." 89

It has been argued above that expropriation without compensation is an unlawful purpose, and it appears that the ad hoc committee and the CLSO agree with this. If these entities do not regard it to be unlawful, however, at the very least they regard it as otherwise improper and deserving of being disguised. This in turn might then not touch on section 25 and constitutional

\footnotetext{
87 Parliament 2021 https://www.youtube.com/watch?v=Pb_bd3bdPZA. The CLSO presentation at around $01 \mathrm{~h} 16 \mathrm{~m} 15$.

Allen 2000 Syd LR 351.

Second Harris judgment 384.
} 
property guarantees, but rather sections $1(\mathrm{~d})$ and $41(1)(\mathrm{c})$ of the Constitution, which require open government and transparency.

Indeed, Roznai observed that one of the implicit limitations on Parliament's constitutional amendment power is that "the amendment power, like any governmental institution, must act in [a] bona fide [way]". He quotes Conrad, who wrote that, "Constitutional destruction [can also occur] by using the form of amendment to directly exercise other constitutional functions in given cases, disregarding constitutional limitations and upsetting the constitutional disposition of powers." Roznai continues, "The overall surrounding circumstances that led to the decision to amend the Constitution in such a way are imperative in the analysis of whether the amending power is being abused or not." 90 It is submitted that Parliament, in the case of expropriation without compensation, if it adopts the ad hoc committee's proposed language and amends the Constitution with whatever majority, will be abusing the amending power.

\subsection{Defeating the spirit of the law}

Secondly ("structuring one's transactions so as to defeat the spirit [or purpose], although not the letter, of the law"), one might argue that fraus legis has taken place if a constitutional amendment defeats the spirit and purpose of the Constitution, without necessarily defeating the text as found in section 74, the amendment power itself.

It is submitted that the Constitution requires a substantive, not merely formal, approach to law and legal reasoning. For this reason, by disguising the terminology of expropriation without compensation in technically though not substantively - legal terminology, the Amendment Bill is aimed at defeating the spirit and purpose of the Constitution. It is attempting to circumvent constitutional values through semantic trickery.

It might be argued at this juncture that nothing stops Parliament from replacing the ad hoc committee's language and in fact simply using the words "without compensation" (rather than for "nil compensation"), and then also removing the words "paid" and "amount" from section 25(3) of the Constitution. This would, some might contend, be within Parliament's ordinary power of amendment in terms of section 74(2) of the Constitution. Such an argument would be based on the notion that what is argued in this article is simply academic and has negligible implications for the legislative process currently underway. It is submitted, however, that such changes to

$90 \quad$ Roznai Unconstitutional Constitutional Amendments 120. 
the Amendment Bill would not solve the problems identified above, viz., that the ad hoc committee is effectively reconceptualising what "expropriation" means per se by divorcing it from necessary compensation; that it is departing radically from international law as well as unchallenged legal custom; and finally, that such an amendment would offend the basic structure of the Constitution.

\subsection{Indirectly doing what cannot be done directly}

Thirdly and finally ("doing indirectly what one is not permitted by law to do directly"), one could argue that fraus legis has taken place if a constitutional amendment seeks to do something unlawful indirectly that cannot be done directly. This final method of achieving fraus legis is, in essence the same as the first discussed above.

According to the CLSO, essentially, the right to the "payment" of an "amount" of compensation still formally stands, but the Amendment Bill would eliminate the substance of this right by making it possible for nil Rands (an "amount") to be "paid". The similarity of this situation to the High Court of Parliament Act as considered in the second Harris judgment is striking. As Van den Heever JA noted in his concurring judgment: ${ }^{91}$

\section{Substantive rights are guaranteed in the constitution; they still 'stand', counsel contended, although by the amendment of adjective law their enforcement may have become impossible. How rights so prostrate can be said to remain 'standing' I cannot grasp - but these are words.}

The Amendment Bill cannot directly allow for expropriation without compensation, as has been acknowledged by the ad hoc committee and the CLSO. Therefore, it allows for expropriation for nil compensation, which indirectly achieves the exact same result. In other words, it is submitted, applied to the Amendment Bill, the right to be "paid" an "amount" in compensation, by operation of the Amendment Bill, would be done away with in substance if not in form.

To understand this phenomenon better, one might imagine an Act that outlaws breathing. South Africans have a right to life guaranteed in section 11 of the Constitution. The hypothetical Act does not directly provide that South Africans must die, which is its direct intention and effect, but achieves this indirectly by saying South Africans may not breathe. Breath is inextricably tied to life, just as compensation is to expropriation. Such an Act would be an instance of fraus legis in public law, allowing the courts to pierce

$91 \quad$ Second Harris judgment 392. 
the veil of form and have regard to its substance, which would by necessary implication render the Act unconstitutional.

\section{Conclusion}

It is trite that substance must enjoy preference over form in any matter of legal consideration, whether adjudication or analysis. This principle applies in the case of the Constitution and its guarantees as well. Sections 25(2) and (3) do not entrench the right to apparent or ostensible compensation upon expropriation of private property but the right to true, bona fide compensation. This is further emphasised by the commitment in section 1(a) of the Constitution that South Africa is founded upon the advancement of human rights and freedoms, not their undermining or weakening.

It should not be too readily assumed that fraus legis cannot or should not apply to constitutional law, and in particular the amendment power of Parliament under section 74 of the Constitution. The dawning of constitutional democracy in South Africa and the entrenchment of the supremacy of the Rule of Law in section 1(c) of the Constitution meant that both the governed and the governing would be bound by the same law, including the fraus legis phenomenon. The notion of princeps legibus solutus est cannot co-exist with the Rule of Law. ${ }^{92}$

The substance of expropriation for nil compensation is expropriation without compensation. Attempting to conceal this fact in formality and thereby attempting to evade the law - whether the requirement of "payment" of an "amount" in compensation, or the intrinsic relation between expropriation as a legal phenomenon and compensation, or the values that underlie our constitutional democracy - is, it is submitted, clearly an instance of the ad hoc committee acting in fraudem legis.

Whether the ad hoc committee and ultimately Parliament will take seriously this allegation that it is engaged in fraus legis is doubtful. But even if the Amendment Bill is adopted into law and section 25 of the Constitution is amended, the courts must construe "nil compensation" for its substance meaning no compensation whatsoever - and have regard to whether such an arrangement satisfies the "just and equitable" standard set in section 25(3). It is submitted that this - construing no compensation as just and

92 Van Staden 2015 Stell LR 561. Although Van Staden and his citations deal exclusively with legislation, it is submitted that the principle applies mutatis mutandis to common law phenomena like fraus legis, as no constitutional provision creates the impression that the State is exempt from such law. 
equitable - is conceivable only in cases on the extreme margin, which would likely render this newfound power of government redundant or merely symbolic. This, however, assumes a conscientious Land Court. ${ }^{93}$ In most cases, as has been argued, though, not paying compensation would be unlawful, offending not only the undisputed values of the Constitution, as found in section 1 and implicit throughout the Bill of Rights, but also international law and practice, including the Universal Declaration of Human Rights; the logic of expropriation itself which necessitates compensation, and the basic structure of the Constitution, wherein property rights are evidently a fundamental characteristic of South Africa's constitutional order.

Whatever the case, the fact that government is bound by the substance and not merely the form of law - especially higher law - is a fact all too often ignored, and the case study of the Amendment Bill illustrates why it ought to be taken seriously.

\section{Bibliography}

\section{Literature}

Allen 2000 Syd LR

Allen T "The Acquisition of Property on Just Terms" 2000 Syd LR 351-380

Beinart 1954 BSALR

Beinart B "Parliament and the Courts" 1954 BSALR 134-181

Buergenthal "International Law and the Holocaust"

Buergenthal T "International Law and the Holocaust" in United States Holocaust Memorial Museum Joseph and Rebecca Meyerhoff Annual Lecture (28 October 2003 Washington DC) 1-25

Derksen 1990 THRHR

Derksen A "Het Daar ' $n$ 'Fraus Legis-Reel' in die Romeinse Reg Bestaan?" 1990 THRHR 502-521

Dunn 1928 Colum L Rev

Dunn FS "International Law and Private Property Rights" 1928 Colum L Rev 166-180

\section{Egerö South Africa's Bantustans}

93 At the time of writing, the Draft Land Court Bill, 2021 had not yet been adopted (or published). The bill proposes the establishment of a permanent Land Court to deal with land reform matters including claims for compensation. 
Egerö B South Africa's Bantustans: From Dumping Grounds to Battlefronts (Nordiska Afrikainstitutet Uppsala 1991)

\section{Epstein 2014 Touro L Rev}

Epstein RA "The Common Law Foundations of the Takings Clause: The Disconnect between Public and Private Land" 2014 Touro L Rev 265-295

Grotius On the Law of War and Peace Book III

Grotius H On the Law of War and Peace Book III (1625) (Liberty Fund Indianapolis 2005)

Hutchison and Hutchison 2014 SALJ

Hutchison A and Hutchison D "Simulated Transactions and the Fraus Legis Doctrine" 2014 SALJ 69-87

Kahn "Oliver Deneys Schreiner"

Kahn E "Oliver Deneys Schreiner: A South African" in Kahn E (ed) Fiat Iustitia: Essays in Memory of Oliver Deneys Schreiner (Juta Cape Town 1983) $1-99$

Langa 2006 Stell $L R$

Langa P "Transformative Constitutionalism" 2006 Stell LR 351-360

Marshall Parliamentary Sovereignty

Marshall G Parliamentary Sovereignty and the Commonwealth (Clarendon Press Oxford 1957)

May South African Constitution

May HJ The South African Constitution (Juta Cape Town 1955)

Oosthuizen Law of Property

Oosthuizen AJ The Law of Property (Juta Cape Town 1981)

Reynolds Before Eminent Domain

Reynolds S Before Eminent Domain: Toward a History of Expropriation of Land for the Common Good (University of North Carolina Press Chapel Hill 2010)

Roznai Unconstitutional Constitutional Amendments

Roznai Y Unconstitutional Constitutional Amendments: A Study of the Nature and Limits of Constitutional Amendment Powers (PhD-dissertation London School of Economics 2014)

Sprankling 2014 Colum J Transnat'l L 
Sprankling JG "The Global Right to Property" 2014 Colum J Transnat'l L 131

Steinmann 2016 PELJ

Steinmann AC "The Core Meaning of Human Dignity" 2016 PELJ 1-32

Van Dorsten 1985 THRHR

Van Dorsten JL "Ulterior Purpose" 1985 THRHR 381-406

Van Staden 2015 Stell LR

Van Staden M "A Comparative Analysis of Common-Law Presumptions of Statutory Interpretation" 2015 Stell LR 550-582

Van Staden 2019 EJW

Van Staden M "The Liberal Tradition in South Africa, 1910-2019" 2019 EJW 258-341

Van Staden 2020 PSLR

Van Staden M "Property Rights and the Basic Structure of the Constitution: The Case of the Draft Constitution Eighteenth Amendment Bill" 2020 PSLR 169-193

Wa Mutua 1997 Harv Hum Rts J

Wa Mutua M "Hope and Despair for a New South Africa: The Limits of Rights Discourse" 1997 Harv Hum Rts J 63-114

Warchuk 2015 UBC Law Rev

Warchuk PA "Rethinking Compensation for Expropriation" 2015 UBC Law Rev 655-692

\section{Case law}

City of Tshwane Metropolitan Municipality v Afriforum 20166 SA 279 (CC)

Collins $v$ Minister of the Interior 19571 SA 552 (A)

Harris $v$ Minister of the Interior 19522 SA 428 (A)

Minister of the Interior v Harris 19524 All SA 376 (A)

Pillai v Mudanayake 19552 All ER 833

\section{Legislation}

Appellate Division Quorum Act 27 of 1955 
Constitution of the People's Republic of China, 1982 (People's Republic of China)

Constitution of the Republic of South Africa, 1996

Constitution of the United States of America, 1789

Group Areas Act 14 of 1950

Group Areas Act 77 of 1957

Group Areas Act 36 of 1966

High Court of Parliament Act 46 of 1951

Native Trust and Land Act 18 of 1936

Natives Land Act 27 of 1913

Natives (Urban Areas) Consolidation Act 25 of 1945

Prevention of Organised Crime Act 121 of 1998

Restitution of Land Rights Act 22 of 1994

Separate Representation of Voters Act 46 of 1951

South Africa Act 9 Edw VII

South Africa Act Amendment Act 9 of 1956

Government publications

Draft Constitution Eighteenth Amendment Bill, 2019

Draft Land Court Bill, 2021

International instruments

African Charter on Human and Peoples' Rights (1981)

American Convention on Human Rights (1978)

Arab Charter on Human Rights (2004)

ASEAN Human Rights Declaration (2012) 
Charter of the United Nations (1945)

Convention on the Elimination of All Forms of Discrimination Against Women (1979)

Convention on the Rights of Persons with Disabilities (2008)

European Convention for the Protection of Human Rights and Fundamental Freedoms (1953)

International Convention on the Elimination of All Forms of Racial Discrimination (1969)

International Convention on the Protection of the Rights of All Migrant Workers and Members of their Families (2003)

Resolution on Respect for the Right of Everyone to Own Property Alone as well as in Association with Others and its Contribution to the Economic and Social Development of Member States UN Doc A/RES/41/132 (1986)

Universal Declaration of Human Rights (1948)

\section{Internet sources}

Azzakani $2021 \quad$ https://www.parliament.gov.za/press-releases/mediastatement-ad-hoc-committee-section-25-adopts-report-public-participation Azzakani R 2021 Media Statement: Ad Hoc Committee on Section 25 Adopts Report on Public Participation https://www.parliament.gov.za/pressreleases/media-statement-ad-hoc-committee-section-25-adopts-reportpublic-participation accessed 22 April 2021

Constitutional and Legal Services Office 2021 https://pmg.org.za/files/210331Annexure_A.docx.

Constitutional and Legal Services Office 2021 Alternative Wording Proposed for the Amendment Bill https://pmg.org.za/files/210331Annexure_A.docx. accessed 19 June 2021

Cronin 2018 https://www.dailymaverick.co.za/article/2018-07-23-its-landreform-not-narrow-expropriation-without-compensation/

Cronin J 2018 It's Land Reform, not Narrow 'Expropriation without Compensation' https://www.dailymaverick.co.za/article/2018-07-23-itsland-reform-not-narrow-expropriation-without-compensation/ accessed 11 March 2021 
Hall 2018 https://www.iol.co.za/capetimes/opinion/landexpropriation-forwhat-land-reform-for-whom-your-land-questions-answered-16370960 Hall R 2018 \#LandExpropriation for What? Land Reform for Whom? Your Land Questions Answered https://www.iol.co.za/capetimes/opinion/ landexpropriation-for-what-land-reform-for-whom-your-land-questionsanswered-16370960 accessed 11 March 2021

Hlomendlini and Makgolane 2017 https://www.blsa.org.za/assets/Uploads/ 2017-July-Possible-impact-of-land-expropriation-on-the-agric-sector-27July2.pdf

Hlomendlini H and Makgolane P 2017 Land Expropriation without Compensation: Possible Impact on the South African Agricultural Economy https://www.blsa.org.za/assets/Uploads/2017-July-Possible-impact-ofland-expropriation-on-the-agric-sector-27-July2.pdf accessed 11 March 2021

Luke 2015 https://www.futuredirections.org.au/publication/challengesconfronting-south-africa-land-reform/

Luke LG 2015 Challenges Confronting South Africa: Land Reform https://www.futuredirections.org.au/publication/challenges-confrontingsouth-africa-land-reform/ accessed 11 March 2021

Moore 2018 https://ruleoflaw.org.za/2018/05/21/whether-expropriationwithout-compensation-would-violate-sas-treaty-or-international-lawobligations/

Moore G 2018 Whether Expropriation without Compensation would Violate SA's Treaty or International Law Obligations https://ruleoflaw.org.za/ 2018/05/21/whether-expropriation-without-compensation-would-violatesas-treaty-or-international-law-obligations/ accessed 11 March 2021

Parliament 2021 https://www.youtube.com/watch?v=Pb_bd3bdPZA Parliament of the Republic of South Africa 2021 Ad Hoc Committee on Legislation Amending Section 25 of the Constitution, [Presentation by Legal Services on the Draft Constitution Eighteenth Amendment Bill; Input by Department of Agriculture, Land Reform and Rural Development on Draft Constitution Eighteenth Amendment Bill], 31 March 2021, Virtual Meeting Platform https://www.youtube.com/watch?v=Pb_bd3bdPZA accessed 23 April 2021

UN Library 2021 https://research.un.org/en/unmembers/founders United Nations Library 2021 Founding Member States https://research.un.org/en/unmembers/founders accessed 22 April 2021 


\section{List of Abbreviations}

BSALR
CLSO
Colum J Transnat'I L
Colum L Rev
EJW
Harv Hum Rts J
PELJ
PSLR
SALJ
Stell LR
Syd LR
THRHR
Touro L Rev
UBC Law Rev
UN

Butterworths South African Law Review Constitutional and Legal Services Office Columbia Journal of Transnational Law Columbia Law Review Econ Journal Watch Harvard Human Rights Journal Potchefstroom Electronic Law Journal Pretoria Student Law Review South African Law Journal Stellenbosch Law Review Sydney Law Review Tydskrif vir Hedendaagse RomeinsHollandse Reg Touro Law Review University of British Columbia Law Review United Nations 